\title{
COMPARISON OF KNOWLEDGE AND ATTITUDES REGARDING HEPATITIS B AMONG STUDENTS OF FACULTY OF MEDICINE, UNIVERSITY OF MOSTAR
}

\author{
Mile Planinić', Svjetlana Grgićz ${ }^{\text {, Jadranka Nikolić }}$
}

(C) 2019 by Acta Medica Saliniana ISSN 0350-364X

DOI: $10.5457 / 518$

Mile Planinić

Svjetlana Grgić

Jadranka Nikolić

\footnotetext{
Afiliations:

${ }^{1}$ Faculty of Medicine, University of Mostar,

${ }^{2}$ Clinic for Infectious diseases, University Hospital Center Mostar, 880oo Mostar, Bosnia and Herzegovina
}

Corresponding author:

Mile Planinić

Email: mile.planinic@gmail.com

\begin{abstract}
Background: Healthcare professionals, including medical and dental students, are at high risk of acquiring hepatitis B infection.

Aim: The aim of this study was to examine and compare the knowledge and attitudes of the students of medicine and dental medicine of Faculty of Medicine, University of Mostar, about hepatitis B.

Subjects and Methods: The examinees in this study were students of the first and second grade of medical studies and studies of dental medicine. The sample included 105 (71.4\%) students of medicine and 42 (28.6\%) students of dental medicine. The study was conducted at the Faculty of Medicine, University of Mostar, through the attached questionnaire.

Results: Overall, the medical students and dental medicine students showed good knowledge about hepatitis B. Medical students showed much more positive attitudes towards hepatitis B positive patients than dental medicine students. Dental medicine students are more concerned about possible infections and general interactions with infected patients, and would statistically significantly reject to provide healthcare services to hepatitis B positive patients compared to the medical students.

Conclusion: It was established that dental medicine students showed a little bit more understanding of the transmission patterns and symptoms of hepatitis B than the medical students. By contrast, medical students showed much more positive attitudes towards patients with hepatitis B than dental medicine students.
\end{abstract}

Key words: hepatitis B, knowledge, attitudes, students of medicine, students of dental medicine

\section{INTRODUCTION}

Hepatitis B is a disease caused by virus of hepatitis B (HBV) that attacks liverand can cause acute or chronic illness. It is assessed that 257 million of people in the world is faced with the HBV infection, and in 2015, 887 ooo death cases were registered, and mostly from complications (including liver cirrhosis and hepatocellular cancer) [1]. Hepatitis B is transmitted by a contact with infected blood and body liquid [2]. The basics of prevention of HBV infection transmission is the usage of standard protection measures and vaccination [3]. The vaccine against hepatitis $B$ has been available since 1982 and has $95 \%$ efficiency in infection prevention and development of chronic hepatitis and hepatocellular cancer [1]. In the Federation of Bosnia and Herzegovina (FB\&H) there is a legally bonded continuous immunization program that is updated once a year by authorized ministry, and it includes the vaccination against hepatitis $B$ [4]. The program of obligatory vaccination against hepatitis B in Bosnia and Herzegovina (B\&H) has existed since 2001 [5].

Concerning the epidemiological data, available data speaks in favor of that Eastern European countries show higher HBsAg positive prevalence in comparison to the countries of West Europe [6-9].Very few data exists on prevention of hepatitis $B$ in B\&H. According to the study conducted in Tuzla Canton (northeastern part of $\mathrm{B} \& \mathrm{H})$, based on ratio estimation method, it was determined that the prevalence in the general population is $1 \%-1.5 \%$, what puts $\mathrm{B} \& \mathrm{H}$ in the group of countries with low endemism for hepatitis B. Similar situation is also with the countries in the surrounding area [5].

The students of medicine are a group of health care workers that are under higher risk for getting blood transmitted 
infections because of their direct contact with the patients, blood and other body liquids during their professional training, and that, combined with the lack of experience and professional skills, increases the risk of infection during the invasive medical procedures [10].

The students of medicine are exposed to the risk of percutaneous injuries similarly, or even more, from health care workers and therefore, they have a higher risk from professional exposition to HBV in comparison with the health care workers, and it can be partially explained with the lack of sufficient level of knowledge in students and non-compliance with general procedures for the infection control [11-12]. According to the available data, in B\&H only one study on knowledge and attitudes towards HBV was conducted, and it was among the students of Faculty of Medicine in Foča [13].Therefore, this study was conceived in a way to compare knowledge and attitudes gained so far, of the medical students and the students of dental medicine of the Faculty of Medicine, University of Mostar, on hepatitis B.

\section{SUBJECTS AND METHODS}

Respondents in this study were students of Medical Faculty of University of Mostar, generally students of first and second grade of the study of medicine, and students of first and second grade of the study of dental medicine. All the respondents had the purpose of study explained to them, and they all participated voluntarily in the study, as evidenced by the signed informed consent. The implementation of the study was approved by the Local Ethics Committee of the Faculty of Medicine of University of Mostar (Date: 06/06/2018; Ref. no. 01-1-741/18). The study was conducted during the specifically determined day in May, 2018 at the same time between aforementioned groups of students.

A specially created questionnaire for assessing knowledge and attitudes on hepatitis B was used in the study (Attachment 1). The questionnaire was totally anonymous and it did not entail entering personal data of the students such as names, surnames, date of birth, etc. It contains minimal sets of questions, which provide an insight in: a) basic data on students, b) knowledge and c) attitudes of the students in regard to hepatitis B.

a) Basic data of students are assessed based on the questions related to the demographic characteristics of the respondents - age, gender, study and city from where the student comes, as well as the questions related to the previous experiences of the student connected to the direct contact with the blood of the other person and testing for blood and sexually transmitted diseases.

b) Knowledge was assessed according to the questions about causative agent, modes of spreading, symptoms, treatment, prognosis and prevention of hepatitis B. That part made a group of 21 questions with three possible answers: YES, NO and I DO NOT KNOW.

c) Attitudes are assessed with a help of 5-level Likert scale that was used to study the level of agreement with a certain assertion ( 1 - totally disagree until 5 - totally agree).

\section{Statistical analysis:}

The collected data was entered into the Microsoft Excel database (version Office 2007, Microsoft Corporation, Redmont, WA, USA), and SPSS for Windows (version 20.0, SPSS Inc. Chicago, Illinois, USA) was used for statistical analysis. Data has been processed using descriptive statistics, and the results of the nominal variables are expressed in absolute $(\mathrm{N})$ and relative (\%) frequencies, and the numeric variables are represented as medians (C) and quartiles (lower and upper, Q1 and Q3). The distribution of the obtained results was tested by the Kolmogorov-Smirnov test. For the testing of the differences between nominal variables, $\chi^{2}$ test has been used, and with the lack of expected frequencies, Fishers exact test has been used.Testing differences in numeric variables was performed by Mann-Whitney's $U$ test. The level of significance is set at $p=0.05$, where $\mathrm{p}$ values less than $0.05(\mathrm{p}<0.05)$ indicate the existence of statistically significant differences. If the $\mathrm{p}$ values cannot be show up to three decimal places, they are shown as $\mathrm{p}<0.001$.

\section{RESULTS}

A sample covered 147 students, and out of them 105 (71.4\%) students of medicine and $42(28.6 \%)$ students of dental medicine. Between the students of medicine $60 \%$ were the students of the first grade, and $40 \%$ the students of the second grade. According to the gender, $71.4 \%$ were female, and $85.6 \%$ are from Bosnia and Herzegovina. In the group of students of dental medicine, the students of the first grade made $57.1 \%$ of the sample, and the students of the second grade $42.9 \%$ of the samples. According to the gender, $73.8 \%$ were female, and $66.7 \%$ are from Bosnia and Herzegovina

More than a half of the students from both study groups had previous experience on direct contact with the blood of the other person ( $52.4 \%$ to $54.8 \%$ ), and over $90 \%$ of them had never tested on blood or sexually transmitted diseases. Both data are without statistical significance between two questioned groups. Based on the questions in the purpose of the comparison of the knowledge of the students, statistically significant difference had been established in 2 questions that are shown in Table 1. 
Table 1. Representation of the questions where the statistically significant difference among the examined groups is established.

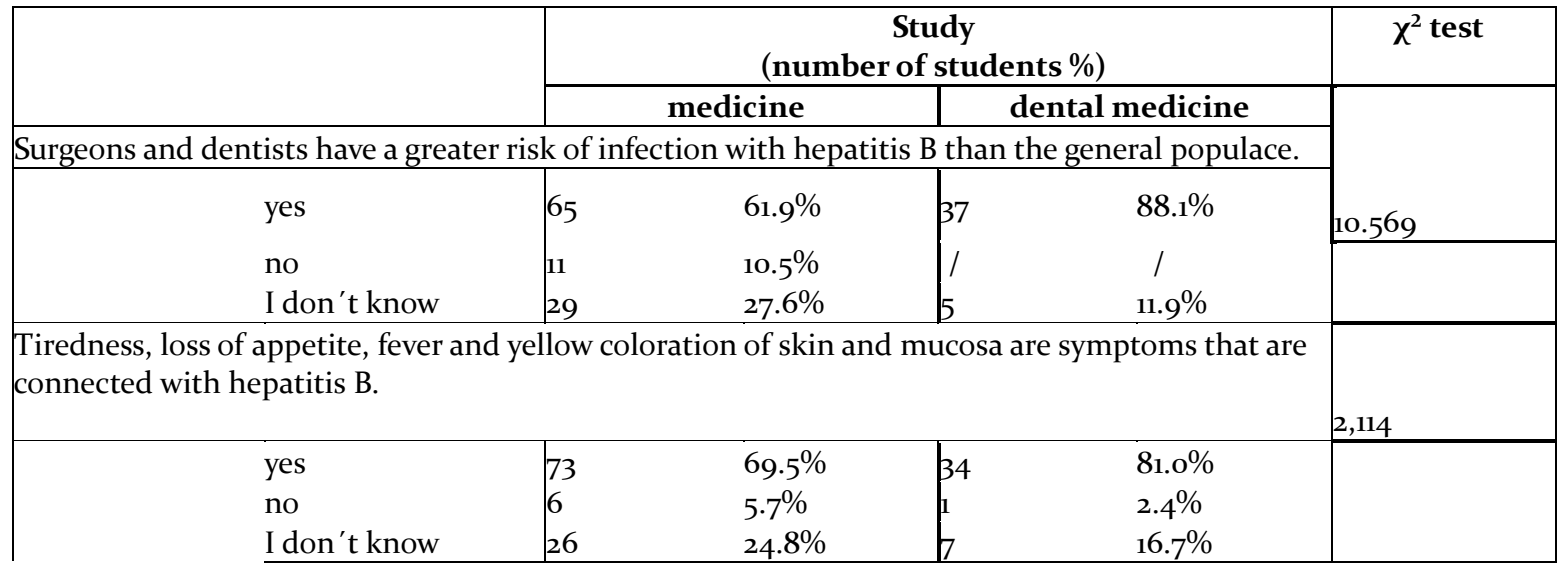

For the testing of the differences between nominal variables, $\chi^{2}$ test has been used, and with the lack of expected frequencies, Fishers exact test has been used, *p<0.05.

There were no statistically significant differences in other questions, and some of those questions are shown in Table 2.

Table 2. Response of some questions about the knowledge of hepatitis B.

\begin{tabular}{|c|c|c|c|c|c|}
\hline & \multicolumn{4}{|c|}{$\begin{array}{c}\text { Study } \\
\text { (number of students \%) }\end{array}$} & $\chi^{2}$ test \\
\hline & & medicine & & dental medicine & \multirow{6}{*}{0.053} \\
\hline \multicolumn{5}{|c|}{ Causative agent of hepatitis B is? } & \\
\hline \multirow{4}{*}{\begin{tabular}{|l|} 
bacteria \\
virus \\
parasite \\
unknown
\end{tabular}} & \multirow{4}{*}{$\begin{array}{l}3 \\
99 \\
0 \\
3\end{array}$} & \multirow{4}{*}{$\begin{array}{ll}2.9 \% \\
94.3 \% \\
\mathrm{o} \\
2.9 \% \\
\end{array}$} & \multirow{4}{*}{$\begin{array}{l}1 \\
40 \\
0 \\
1\end{array}$} & \multirow{4}{*}{$\begin{array}{l}2.4 \% \\
95.2 \% \\
0 \\
2.4 \% \\
\end{array}$} & \\
\hline & & & & & \\
\hline & & & & & \\
\hline & & & & & \\
\hline \multicolumn{5}{|c|}{ Causative agent of hepatitis B is $50-100$ times more infective than HIV. } & \\
\hline yes & 18 & $17.1 \%$ & 12 & $28.6 \%$ & \multirow{3}{*}{2.415} \\
\hline no & 17 & $16.2 \%$ & 6 & $14.3 \%$ & \\
\hline I don't know & 70 & $66.7 \%$ & 24 & $57.1 \%$ & \\
\hline \multicolumn{5}{|c|}{ Causative agent of hepatitis B is sensitive to low temperature, dryness and UV-radiation. } & \multirow{4}{*}{1.600} \\
\hline yes & 25 & $23.8 \%$ & 10 & $23.8 \%$ & \\
\hline no & 8 & $7.6 \%$ & 6 & $14 \cdot 3 \%$ & \\
\hline I don't know & 72 & $68.6 \%$ & 26 & $61.9 \%$ & \\
\hline \multicolumn{5}{|c|}{ Hepatitis B can be transmitted sexually. } & \\
\hline yes & 80 & $76.2 \%$ & 28 & $66.7 \%$ & \multirow{3}{*}{4.459} \\
\hline no & 11 & $10.5 \%$ & 10 & $23.8 \%$ & \\
\hline I don't know & 14 & $13.3 \%$ & 4 & $9.5 \%$ & \\
\hline \multicolumn{5}{|c|}{$\begin{array}{l}\text { Hepatitis B can be transmitted by close contact of eye mucosa with blood and saliva of the } \\
\text { infected person. }\end{array}$} & \\
\hline yes & 70 & $66.7 \%$ & 32 & $76.2 \%$ & \multirow{3}{*}{1.287} \\
\hline no & 11 & $10.5 \%$ & 3 & $7.1 \%$ & \\
\hline I don't know & 24 & $22.9 \%$ & 7 & $16.7 \%$ & \\
\hline \multicolumn{5}{|c|}{ Best way of prevention is vaccination. } & \\
\hline yes & 82 & $78.1 \%$ & 35 & $83 \cdot 3 \%$ & \multirow{3}{*}{0.539} \\
\hline no & 4 & $3.8 \%$ & 1 & $2.4 \%$ & \\
\hline I don't know & 19 & $18.1 \%$ & 6 & $14.3 \%$ & \\
\hline
\end{tabular}

For the testing of the differences between nominal variables, $\chi^{2}$ test has been used, and with the lack of expected frequencies, Fishers exact test has been used, * $p<0.05$. 
Based on the claims set for the comparison of the attitudes, it was noted that the students of medicine and the students of dental medicine are significantly different in their attitudes regarding the hepatitis B. Statistical significance was established in 5 claims shown in Table 3.

Table 3. Representation of claims where the statistically significant difference among the examined groups is established.

\begin{tabular}{|c|c|c|c|c|c|c|}
\hline \multirow{3}{*}{ Claims } & \multicolumn{6}{|c|}{ Study } \\
\hline & \multicolumn{3}{|c|}{ medicine } & \multicolumn{3}{|c|}{ dental medicine } \\
\hline & $\mathrm{C}$ & Q1 & Q3 & C & Q1 & Q3 \\
\hline $\begin{array}{l}\text { T1: I have a moral obligation to treat hepatitis B } \\
\text { positive patients. }\end{array}$ & 5.0 & 5.0 & 5.0 & 4.0 & 4.0 & 5.0 \\
\hline $\begin{array}{l}\text { T3: I would refuse treatment to hepatitis B infected } \\
\text { person. }\end{array}$ & 1.0 & 1.0 & 1.0 & 2.0 & 1.0 & 3.0 \\
\hline $\begin{array}{l}\text { T4: I worry about potential infection with hepatitis B } \\
\text { from my patients. }\end{array}$ & 3.0 & 2.0 & 4.0 & 4.0 & 3.0 & 5.0 \\
\hline $\begin{array}{l}\text { T6: Handshakes and conversations with hepatitis B } \\
\text { infected person give me discomfort. }\end{array}$ & 2.0 & 1.0 & 3.0 & 3.0 & 2.0 & 4.0 \\
\hline $\begin{array}{l}\text { T7: I would give equal service to both hepatitis B } \\
\text { infected patients and non-infected patients. }\end{array}$ & 5.0 & 5.0 & 5.0 & 4.0 & 4.0 & 5.0 \\
\hline
\end{tabular}

$C$ - median; $Q_{1}$ - first (lower) quartile; $Q_{3}$ - third (upper) quartile; Mann-Whitney U test; ${ }^{*} p<0,05$.

\section{DISCUSSION}

Our study found that dental medicine students showed a slightly higher level of knowledge about hepatitis B compared to medical students in terms of risk factors for the transmission of HBV and symptoms. On the other hand, medical students showed significantly more positive attitudes toward HBV positive patients compared to dental medicine students. Most of our respondents are female and originate from $\mathrm{B} \& \mathrm{H}$.

The knowledge of our respondents could be estimated to be approximately satisfactory. Of the 21 questions asked, for the 16 questions the percentage of correct answers was above $50 \%$ in both groups. We must also consider the fact that the respondents are students of the first two grades of faculty and that there is still plenty of space to improve their level of knowledge on this important topic. In most similar studies on this topic, there was a lack of student knowledge of most aspects of HBV infection [14-18], while on the other hand there are studies where the level of knowledge was assessed positively [19-20].

Based on the question of our current experience of blood and sexually transmitted diseases, most of them have come into direct contact with the blood of another person, while most of them have never been tested on blood and sexually transmitted diseases. Similar test data were recorded in a study conducted in Ethiopia among medical and healthcare students, where $90 \%$ of them responded that they have never been tested on blood-transmitted diseases [19].

Examining knowledge about hepatitis B causative agent, there has not been found a statistically significant difference between the two examined groups. Nearly all respondents recognized the virus as a causative agent and liver as the target organ of hepatitis B. Conversely, most of the respondents didn 't know HBV infectivity with respect to the human immunodeficiency virus (HIV) and the sensitivity of HBV to external factors. The reason for such a poor knowledge of these issues could be explained by the fact that such information is more readily available on clinical subjects later in the faculty, when students are more fully acquainted with all aspects of HBV infection. A similar result was presented in a Chinese study where only $12.5 \%$ of medical students and $16.2 \%$ of dentistry students knew that HBV was not susceptible to low temperature, dryness and UV radiation [21].

By examining the knowledge about the transmission patternsand the risk factors for hepatitis B development, students of dental medicine have statistically significantly more often known that surgeons and dentists have a higher risk of HBV infection than the general population compared to the medical students. There were no statistically significant differences among the examined groups on the other questions about the transmission patterns. Particularly, we would like to emphasize the fact that $76.2 \%$ of dentistry students knew that hepatitis B could be transmitted by contacting the eye mucosa with the blood and saliva of the infected person. This is important because of the nature of the dentist's work. By using dental equipment and aids, large volumes of aerosols containing saliva and blood are produced, so the potentially infectious material is in a position to come into contact with the conjunctive of the dentist himself [22-23]. According to the study of blood-transmitted disease pathogens amongst dentists in Poland, $55 \%$ of the reported exposures made the contact of infectious material with the eye mucosa [24].

Dental medicinestudents have statistically significantly more often recognized tiredness, loss of appetite, fever, and yellow skin and mucous skin as symptoms 
associated with hepatitis B compared to the students of medicine. Other authors did not investigate the symptoms of the disease in their studies.

Examination of knowledge on the basis of questions on hepatitis B prevention also revealed no statistically significant difference between the two groups.

We emphasize that most respondents recognize the role and importance of vaccination in preventing hepatitis B as well as the importance of using protective equipment in everyday work. Similar results are also reported by a study at the Faculty of Medicine in Foča $(\mathrm{B} \& \mathrm{H})$, where $93.5 \%$ of them consider vaccination as the most important measure for the prevention of hepatitis B [13]. Likewise, some other studies show similar results [17-20]. Attitudes of the students on HBV positive patients were estimated based on 10 claims set and 5 offered responses of intensities reflecting a higher or lower degree of agreement with a particular statement. A statistically significant difference was found in half of the claims.

The students of medicine have shown more empathy towards the patients and statistically more often agreed with more positive statements than dental medicine students. Thus, medical students consider their moral obligation to treat HBV infected patients and agree to provide infected patients with the same level of service as all other patients. On the other hand, dental medicine students are more concerned about being infected by their patients and would more often refuse to provide a health service to a HBV positive patient compared to their medical colleagues. Also, a greater number of dental medicine students consider the usual interaction with a HBV positive patient to be "discomfort".

Quite similar results were presented in a Chinese study where dental medicine students showed less willingness to treat $\mathrm{HBV}$ infected patients compared to medical students, with the emphasis that student's attitudes are becoming more positive as they are more likely to encounter and work with infected patients [21]. In contrast, the results of Pakistan study suggest that dental medicine students with more knowledge have shown greater willingness to treat patients with illness [18].

It is interesting to note that $81 \%$ of Polish dentists are concerned about possible HBV infection during their work, and a quarter of dentists admitted that they were refusing to provide their patient with a service that was considered rather worrying [24]. From the call of the doctors' and dental practitioners it follows, both ethical and legal, that the doctor is obliged to provide assistance to all, while respecting the human rights and dignity of the person. The limitation of this study is a small number of respondents, and that only the first and second grade students of medicine and dental medicine are involved in the study. The reason for this is that the faculty of dental medicine at the Faculty of
Medicine in Mostar started with work in 2016, which means that only the first two generations of students were enrolled at the time of our study. Accordingly, study on the faculty of medicine was performed only in the first two grades of faculty so that the comparison between the two groups was more representative.

The authors of most of the available studies highlighted the correlation between the level of knowledge and expressed attitudes, where the more knowledgeable respondents showed more positive and less discriminatory attitudes towards infectious diseases [25-27]. In our case, dental medicine students have shown some better knowledge of the subject, which may be related to the fact that they are more aware of the dangers of contagious diseases due to the specific nature of their future occupation. However, this increased awareness can also result in excessive, unjustified fear of such patients, which contributes to the expression of negative attitudes. We believe that further learning and development of knowledge about this disease is needed and we believe that achieving a true degree of knowledge and understanding of medical facts will result that future doctors and dentists make their call for the benefit of each patient without prejudice.

\section{CONCLUSION}

It was established that dental medicine students showed a little bit more understanding of the transmission patterns and symptoms of hepatitis B than the medical students. By contrast, medical students showed much more positive attitudes towards patients with hepatitis $\mathrm{B}$ than dental medicine students.

\section{SAŽETAK}

Uvod: Zdravstveni djelatnici, uključujući studente medicine i dentalne medicine, spadaju u visokorizičnu skupinu za stjecanje hepatitis B infekcije.

Cilj: Cilj ovog istraživanja je bio ispitati i usporediti dosadašnje znanje $\mathrm{i}$ stavove studenata medicine $\mathrm{i}$ studenata dentalne medicine Medicinskog fakulteta Sveučilišta u Mostaru o hepatitisu B.

Materijal i metode: Ispitanici u ovom istraživanju su bili studenti prve i druge godine studija medicine i studija dentalne medicine. Uzorak je obuhvatio 105 (71.4\%) studenata medicine i 42 (28.6\%) studenta dentalne medicine. Istraživanje je provedeno na Medicinskom fakultetu Sveučilišta u Mostaru uz pomoć anketnog upitnika.

Rezultati: Studenti medicine i studenti dentalne medicine su pokazali dobro znanje o hepatitisu B. Studenti medicine su iskazali znatno pozitivnije stavove prema oboljelima od hepatitisa B, za razliku od studenata dentalne medicine. Studenti dentalne medicine su više zabrinuti oko moguće zaraze i općenito interakcije s oboljelim pacijentima, te bi statistički značajno češće odbili pružiti zdravstvenu skrb hepatitis B pozitivnom pacijentu, za razliku od studenata medicine. 
Zaključak: Utvrđeno je da su studenti dentalne medicine pokazali nešto bolje poznavanje i razumijevanje načina prijenosa i simptoma hepatitisa $\mathrm{B} \mathrm{u}$ odnosu na studente medicine. S druge strane, studenti medicine su pokazali značajno pozitivnije stavove prema oboljelima od hepatitisa B.

Ključne riječi: hepatitis $B$, znanje, stavovi, studenti medicine, studenti dentalne medicine

\section{REFERENCES}

1. The World Health Organization (2018) Media Centre. Hepatitis B. Accessed by March 2019. Available from: http://www.who.int/en/newsroom/fact-sheets/detail/hepatitis-b

2. MacLachlan JH and Cowie BC. Hepatitis B virus epidemiology. Cold Spring Hardb Perspect Med 2015; 5: a021410.

3. Holmberg SD, Surya Prasad A, Ward JW. Updated CDC recommendations for the management of hepatitis B virus-infected health-care providers and students. US Department of Health and Human Services, Centers for Disease Control and Prevention 2012; 61: 542.

4. Ministry of Health (Federation of Bosnia and Herzegovina): Recommended immunization schedule for children and adolescents aged 18 years or younger - FB\&H (2017). Accessed by March 2019. (Croatian). Official Gazette of the Federation BIH, No. 19/17. Available from: http://www.fmoh.gov.ba/images/federalno ministarstvo zdravstva/preporucujemo/ istrazivanja/Naredba o imunizaciji-19 17.pdf

5. Petrovic J, Salkic NN, Ahmetagic S, Stojic V and Mott-Divkovic S. Prevalence of Chronic Hepatitis B and Hepatitis C among First Time Blood Donors in Northeast Bosnia and Herzegovina: An Estimate of Prevalence in General Population. Hepat Mon 2011; 11: 629633.

6. Lazarevic I, Cupic M, Delic D, Svirtlih NS, Simonovic J, Jovanovic T. Distribution of HBV genotypes, subgenotypes and HBsAg subtypes among chronically infected patients in Serbia. Arch Virol 2007; 152: 2017-2025.

7. Lazarevic I, Cupic M, Delic D, Svirtlih NS, Simonovic J, Jovanovic T. Prevalence of hepatitis B virus MHR mutations and their correlation with genotypes and antiviral therapy in chronically infected patients in Serbia. J Med Virol 2010; 82: 1160-1167.

8. Liaw YF, Brunetto MR, Hadziyannis S. The natural history of chronic HBV infection and geographical differences. Antivir Ther 2010; 15: 25-33.

9. Tekin Koruk S, Koruk I, Gursoy B, Çalisir C, Kuksell F, Yildiz Zeyrek F. Hepatitis B and Hepatitis C Seroprevalence in the Center of Sanliurfa Province From Southeastern Anatolia Region and Related Risk Factors. Balkan Med J 2010; 27: 367-372.
10. Ibrahim N, Idris A. Hepatitis B Awareness among Medical Students and Their Vaccination Status at Syrian Private University. Hepatitis Study and Treatment 2014; 2014: 7.

11. Nagandla K, Kumar K, Bhardwaj A, Muthalagan D, Yhmin C, Lun LW, et al. Prevalence of needle stick injuries and their underreporting among healthcare workers in the department of obstetrics and gynecology. Int Arch Med 2015; 8: 1-16.

12. Chouhan S. Hepatitis B Prophylaxis practice among medical students. An overview. Hep B Annu 2008; 5: 102-116.

13. Joksimovic B, Mijovic B, Jankovic S. The knowledge, attitudes and behavior of medical students toward hepatitis B virus infection. Biomedicinska istrazivanja 2010; 1: 48-55.

14. Rathi A, Kumar V, Majhi J, Jain S, Lal P, and Singh S. Assessment of knowledge, attitude, and practices toward prevention of hepatitis $B$ infection among medical students in a highrisk setting of a newly established medical institution. J Lab Physicians 2018; 10: 374-379.

15. Mesfin YM, and Kibret KT. Assesment of knowledge and practice towards hepatitis $\mathrm{B}$ among medical and health science students in Haramaya University, Ethiopia. PLoS One 2013; 8: e79642.

16. Othman SM, Saleh AM, and Shabila NP. Knowledge about hepatitis B infection among medical students in Erbil city, Iraq. Europ Sci J. 2013; 3: 1857-1881.

17. Al-Shamiri HM, ALShalawi FE, AlJumah TM, AlHarthi MM, AlAli EM, and AlHarthi HM. Knowledge, attitude and practice of hepatitis $B$ virus infection among dental students and interns in Saudi Arabia. J Clin Exp Dent 2018; 10: e54-e6o.

18. Ali A, Khan S, Malik SM, Iqbal MH, Aadil M. Comparison of knowledge and attitudes regarding hepatitis $\mathrm{B}$ among healthcare professionals in Pakistan. Cureus 2017; 9: e1049.

19. Abdela A, Woldu B, Haile K, Mathewos B, and Deressa T. Assessment of knowledge, attitudes and practices toward prevention of hepatitis B virus infection among students of medicine and health sciences in Northwest Ethiopia. BMC Res Notes 2016; 9: 410.

20. Alhowaish MA, Alhowaish JA, Alanazi YH, Alshammari MM, Alshammari MS, Alshamari NG, Alshammari AS, Almutairi MK, and Algarni SA. Knowledge, attitudes and practices toward prevention of hepatitis $B$ virus infection among medical students at Northern Border University, Arar, Kingdom of Saudi Arabia. Electron Physician 2017; 9: 53885394.

21. Li x, Kang H, Wang S, Deng Z, Xang T, Jia Y and Yang Y. Knowledge, attitude, and behavior of hepatitis B virus infection among chinese dental interns. Hepat Mon 2015; 15: e25079. 
22. Harrel SK, Molinari J. Aerosols and splatter in dentistry: A brief review of the literature and infection control implications. J Am Dent Assoc 2004; 135: 429-437.

23. Shimoji S, Ishihama K, Yaamada H, Okayama M, Yasuda K, Shibutani T, Ogasawara T, Miyazawa H, and Furusawa K. Occupational safety among dental health-care workers. Adv Med Educ Pract 2010; 1: 41-47.

24. Garus-Pakowska, Gorajski M, and Szatko F. Knowledge and attitudes of dentists with respect to the risks of blood-borne pathogens - A cross-sectional study in Poland. Int J Environ Res Public Health 2017; 14: 69.

25. Ul Haq N, Hassali MA, Shafie AA, Saleem F, Farooqui M, and Aljadhey H. A cross sectional assessment of knowledge, attitude and practice towards Hepatitis B among healthy population of Quetta, Pakistan. BMC Public Health 2012; 12: 692.

26. Singh A, Purohit BM, Bhambal A, Saxena S, Sing A, and Gupta A. Knowledge, attitudes, and practice regarding infection control measures among dental students in Central India. J Dent Educ 2011; 75: 421-427.

27. Jafari A, Yazdani R, Khami MR, Mohammadi $M$, and Hajiabdolbaghi $M$. Effect of an educational course at an Iranian dental school on student's knowledge of and attitudes about HIV/AIDS. J Dent Educ 2012; 76: 792-799.

Scan this QR code with your mobile device for instant access to the current Issue of Acta Medica Saliniana

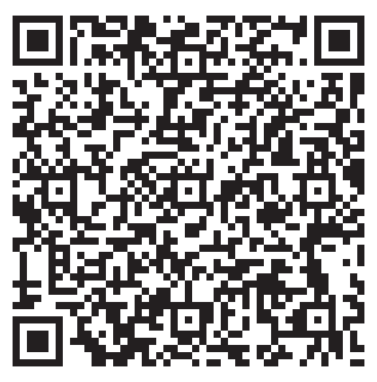

